\title{
Law and Medicine: Notes on the Meeting of German- Speaking Public Law Assistants in Vienna (2006)
}

\author{
By Marten Breuer
}

Meetings of German-speaking Public Law assistants have, as was explained in Daniel Thym's report on the Bielefeld meeting in 20051, been a long-standing tradition. Therefore, it is not surprising that the Austrian capital has already seen four meetings of this kind, in 1970, 1981, 1994 and now in 2006. More than 150 Public Law assistants from Germany, Switzerland and (needless to say) Austria convened from 21 to 24 February in order to discuss the implications of the general topic "Law and Medicine"2. In accordance with the European idea, the circle of participants was not restricted to assistants coming from those three countries but the organizers had successfully encouraged German-speaking assistants from other EU countries to make contributions. Indeed, European law, in terms of contents, also played a major role.

The first day was particularly dominated by European issues. Under the heading "Human Dignity, Biomedicine and European Public Order", Klaus Gärditz (Bayreuth) skeptically assessed the possibilities of agreeing on a common legal notion of "human dignity" in Europe. As for Community Law, this notion must be defined in accordance with Art. 6 (2) EU, i.e. by recourse to the European Convention on Human Rights (ECHR) and to the constitutional traditions common to the Member States. In biomedical matters, however, the ECHR does not always give clear guidance. This can be demonstrated by the case of Vov. France where the European Court of Human Rights (Eur. Court H.R.) observed that there is no consensus on the nature and status of the embryo and/or fetus. Therefore, it was unable to answer in the abstract the question whether the unborn child is a person

\footnotetext{
- Dr. Marten Breuer: Academic Assistant at the Law Faculty of the University of Potsdam, online at: http://www.marten-breuer.de.

I Daniel Thym, The European Constitution: Notes on the National Meeting of German Public Law Assistants, 6 GERMAN LAW JOURNAL No. 4 (1 April 2005) at: http://www.gemanlawjournal.com /article.php?id=593.

2 For further information (including the papers of all presentations), see http:// www.assistententagung.at.
} 
for the purposes of Art. 2 ECHR ${ }^{3}$. The Convention on Human Rights and Biomedicine from 1997 is not ratified by all EU Member States. Besides, it prohibits the creation of human embryos only for research purposes (Art. 18 (2)) and contains no provisions for so-called surplus embryos. Therefore, it does not reflect but the least common denominator in Europe. The constitutional traditions of the EU Member States are too diverse in biomedical matters for clearer results.Finally, the Charter of Fundamental Rights, even if it were legally binding, in its Art. 3 (2) mainly reflects the minimum standard of the Convention on Biomedicine. This general outline was confirmed by the jurisprudence of the European Court of Justice (ECJ). In the case concerning Directive 98/44/EC on the legal protection of biotechnological inventions, the $\mathrm{ECJ}$ found that it was ensured that the human body effectively remained unavailable and inalienable and that human dignity was thus safeguarded ${ }^{4}$. This might reflect what could be called a European core content of human dignity. In the Omega case, however, the ECJ indicated that there may be different concepts of human dignity amongst the Member States. 5 . Given that according to Art. 6 (3) EU, the EU has to respect the national identities of its Member States, Gärditz concluded that the EU must not fund biomedical research projects which were in contradiction to at least one Member State's concept of human dignity. This provocative thesis, of course, was strongly opposed to in the subsequent debate.

The next two presentations dealt with the question of EC competencies in health matters. Martin Kment (Münster) concentrated on the crosscutting clause contained in Art. 152 EC. Generally, the Community has very few competencies under this article. Nonetheless, Kment held that the crosscutting clause must be construed as being legally binding. In order to make it operational, he infered from it the requirement of making a "health impact assessment" before taking EC measures. $\mathrm{He}$ also deduced additional formal requirements such as participation, data collection, documentation and reasoning. These proposals were apparently inspired by parallel provisions of EC environmental law. However, in the subsequent discussion, the objection was raised that in environmental law the said requirements were laid down in EC directives, whereas in health matters no such directives existed. Furthermore, it was questioned whether it made sense to create more and more crosscutting clauses. If every concern had to be taken into consideration, one ended where one had previously started. Marjolaine Savat (Frankfurt am Main), a French national, took a different approach. Her starting

\footnotetext{
${ }^{3}$ Eur. Court H.R., Vo v. France, 2004-VIII., paras. 84-85.

4 Case C-377/98, Netherlands v. Parliament and Council, 2001 ECR I-7079, para. 77.

${ }^{5}$ Case C-36/02, Omega, 2004 ECR I-9609, para. 37.
} 
point was that in times of BSE and SARS, it became increasingly difficult to take effective measures at the national level. Therefore, she held that in health matters, the principle of subsidiarity (Art. $5 \mathrm{EC}$ ) by virtue of its "better clause"6 might evolve to a "light version" of the kompetenz-kompetenz on the part of the Community ${ }^{7}$. As she explained later, her idea had been to transpose the so-called "théorie de la tâche d'huile" known from French administrative law to the European situation. Her position was, however, strongly opposed given the fact that the principle of subsidiarity was applicable only where the Community already has competencies, in accordance with the principle of limited individual powers.

Kerstin Wolny (Erlangen) exceeded the European dimension in her presentation on "Bioterrorism as a Challenge for Public International Law". She explained that so far, the general focus in public international law had been on prevention. In 1975, the Biological Weapons Convention ${ }^{8}$ was concluded and in 2001, a protocol to the Convention was proposed but has not yet entered into force. However, the general problem was that these instruments were solely state-directed. With respect to biological weapons though, non-state actors formed a threat equal to that of states. Therefore, her proposal was to use international criminal law in order to fill the gap. In this context, she explored the possibilities of prosecuting acts of bioterrorism before the International Criminal Court (ICC) in The Hague. The problem here is that the Court's jurisdiction is limited to four categories of crimes: aggression, war crimes, crimes against humanity and genocide (Art. 5 (1) ICC Statute). As for the crime of aggression, it can be perpetrated only by states; besides, the ICC Statute is imperfect in so far as it leaves the definition of this category to future developments (Art. 5 (2) ICC Statute). If an act of bioterrorism is committed in times of war, it could in principle be regarded as a war crime within the meaning of Art. 8 ICC Statute. This result, however, is rebutted by the fact that when the ICC Statute was concluded, the States Parties wanted to exclude both atomic and biological weapons from the scope of this provision. Wolny's solution was that under certain conditions, acts of bioterrorism may form a crime against humanity (Art. 7 ICC Statute). In particular, she argued that this provision had an objective different from that of war crimes. Therefore, the fact that bioterrorism could not be

6 "... if and in so far as the objectives of the proposed action ... can ... be better achieved by the Community".

7In her presentation, Savat avoided to use the term "light version", which had appeared in her paper (see note 2). Instead, she referred to a possible "de facto competence" of the Community in health matters. In the discussion, however, it was the expression "light version" which attracted most attention.

8 Convention on the Prohibition of the Development, Production and Stockpiling of Bacteriological (Biological) and Toxin Weapons and on Their Destruction. 
regarded as a war crime was not decisive for the interpretation of crimes against humanity. In the debate, she was confronted with the observation that according to Art. 32 of the Vienna Convention on the Law of Treaties, the preparatory work of a treaty and the circumstances of its conclusion are merely supplementary means of interpretation where the meaning is ambiguous or obscure. Therefore, the question was raised whether in juridical terms, it was at all possible to take into account the states' will to exclude biological weapons from the scope of Art. 8 ICC Statute. In her answer, Wolny underlined that the ICC mainly depended on the cooperation of the States Parties; therefore, it was dangerous to ignore their will.

During the second day, the (German) national perspective was dominant. Gregor Kirchhof (Bonn) made a very inspiring contribution with the aim of ensuring a better interrelation of fundamental rights and reality, exemplified by selective problems encountered by physicians. His approach was twofold. First, he proposed to distinguish between different categories of medical treatment. In contrast to curative acts (Heilbehandlung), acts of renewal (Erneuerungseingriffe) such as e.g. hip replacements do not simply cure accidental diseases but are the result of an everaging population. He argued that the legal order must reflect these differences. Second, he came to a peculiarity of German constitutional law. Compliance with fundamental rights is generally examined in a three step procedure. (1) Does the contested measure concern the protected scope (Schutzbereich) of a given fundamental right? (2) Does the contested measure constitute an impairment (Eingriff) of the protected scope? (3) Is the impairment justified (Rechtfertigung)? Due to this procedure, it is impossible - in Kirchhof's view - to take account of cumulative burdens because only one single measure is examined 9 . This was demonstrated by the example of physicians practicing in Germany. Up to $25 \%$ of their work had nothing to do with medicine but consisted of purely administrative tasks. Where these tasks could be equally done by nurses, the cumulative burdens of practicing physicians were in breach of their constitutional rights. However, Kirchhof's assessment that it was impossible to take account of cumulative burdens due to the said three step procedure was contradicted. In the third step (justification), the proportionality of a given measure has to be examined. Here, cumulative burdens could well have the effect of making a single measure disproportioned. One example of cumulative burdens in the jurisprudence of the German Federal Constitutional Court was the GPS decision of 12 April 200510. This decision, though,

9 See also GrEGor KIrChHOF, KUMULATIVE BELASTUNG DURCH UNTERSCHIEDLICHE STAATLICHE MASSNAHMEN, NEUE JURISTISCHE WOCHENSCHRIFT (2006), 732-736.

10 See Nicole Jacoby, The Decision of the Bundesverfassungsgericht of April 12, 2005 Concerning Police Use of Global Position Systems as a Surveillance Tool, 6 GERMAN LAW JOURNAL No. 7 (1 July 2005), at: http://www.germanlawjournal.com/article.php?id=615; Jacqueline Ross, Germany's Federal 
is still solitary so that Kirchhof's deepening of legal theory in this respect has to be welcomed.

Another interesting contribution was made by Torsten Hartleb (Freiburg im Breisgau). He dealt with extracorporeal embryos and their status under the German Basic Law. Among German constitutional lawyers, it is still the predominant position that extracorporeal embryos have full rights under Art. 1 (human dignity) and Art. 2 (2) (right to life) of the Basic Law. Hartleb demonstrated, though, that it is difficult to reach this result by use of the ordinary methods of interpretation. The only way in his view is to have recourse to the so-called CIP trilogy developed by the ethical sciences; the abbreviation "CIP" standing for "continuity", "identity" and "potentiality". In Hartleb's opinion, it is primarily the potentiality argument which speaks in favor of the equation of extracorporeal embryos and born children. However, most recent medical developments, such as so-called knockout embryos, demonstrated that this argument could not solve all existing problems. He then strongly opposed any attempt to accord extracorporeal embryos the right to life but not human dignity. This was for the reason that "every person" (Art. 2 (2) of the Basic Law) necessarily is a human being and therefore must have "human" dignity (Art. 1 of the Basic Law). At the end of his presentation, he demonstrated that there are two situations in which the concept fails. These are, on the one hand, cases where extracorporeal embryos have not yet come into existence; and on the other hand, cases where extracorporeal embryos have been created but the woman has changed her mind and does not want to have the baby any longer. This issue was further discussed in the afternoon in a high ranking panel discussion including members of the Austrian national ethics council.

Earlier, Franziska Sprecher (Heidelberg) gave valuable insights in the vulnerable position of children in medical research projects. She based her analysis on a comparative law overview of Swiss, German and Austrian law including the Council of Europe's Convention on Biomedicine and the European Community's medicinal products directive ${ }^{11}$. The directive was found to follow a "paternalistic" concept in that it required, under all circumstances, the informed consent of a child's parents or legal representative before commencing a clinical trial on a minor. In contrast, the Convention on Biomedicine was described as following an "individualistic" concept since interventions are allowed without the authorization of a child's representative where the child has the capacity to consent. These two legal instruments are also different in another respect. Under the medicinal products directive, some direct benefit for the group of patients is sufficient to

Constitutional Court and the Regulation of GPS surveillance, 6 GERMAN LAW JOURNAL No. 12 (1 December 2005), at: http://www.germanlawjournal.com/article.php?id=678.

${ }^{11}$ Directive 2001/20/EC. 
allow clinical trials on minors, whereas under the Convention on Biomedicine, an intervention may only be carried out on minors for his or her direct benefit. Austria and Germany, both being EU Member States, were found to follow the medicinal products directive. Switzerland, on the other hand, mainly followed the concept of the Convention on Biomedicine. Most interestingly, a Law on Human Research (Humanforschungsgesetz) is currently under way in Switzerland which is going to alter the legal situation of minors in the field of medical research.

The last day was opened by a contribution by Elisabeth Greif (Linz) on the issue of transsexuality. Three legal aspects were concerned. Post-operative transsexuals might have the wish to change their registered sex, to change their names and/or to marry. In this context, the jurisprudence of the Eur. Court H.R. has brought about considerable changes in Europe. In 2002, the Court gave up its well-established jurisprudence and acknowledged what could be called a "right to sexual identity"12. Nonetheless, Greif argued that the Eur. Court H.R. was stuck halfway as it focused on operative solutions. In the subsequent discussion, however, she offered no alternative concept in which legal differences between men and women were abandoned.

Atina Krajewska (Wroclaw, Poland) then dealt with "The Legal Protection of Genetic Information in the European Context". She began with an example from Iceland. The Icelandic Health Sector Database (HSD) contained the genetic data of all Icelandic people. In the case of Ragnhildur Guðmundsdóttir $v$. Iceland, a daughter objected to the transfer of data belonging to her deceased father to the HSD. In a landmark decision of 27 November 2003, the Icelandic Supreme Court struck down the HSD Act as unconstitutional ${ }^{13}$. Krajewska then explained that in legal terms, there were two possible ways of dealing with genetic data: a property-oriented and a privacy-oriented approach. Unlike what she had written before in her paper ${ }^{14}$, she now clearly favored the second option. Of course, to regard genetic data as some kind of "property" has the advantage of legal certainty, transparency and negotiability. On the other hand, allowing negotiations of genetic data raises the problem of the commercialization of human life. Krajewska also found that the immaterial nature of genetic data formed an obstacle to the property-oriented concept. Here, she followed a very narrow interpretation of the notion "property". Thirdly, she reminded that genetic information did not only concern one single person but to a certain extent also the family members. Therefore, she questioned

${ }_{12}^{2}$ Eur. Court H.R., Christine Goodwin v. The United Kingdom, 2002-VI; Eur. Court H.R., I v. The United Kingdom, App. No. 25680/94, 11 July 2002.

${ }^{13}$ See http://www.mannvernd.is/english/lawsuits/Icelandic_Supreme_Court_Verdict_151_2003.pdf.

${ }^{14}$ See supra note 2. 
that genetic information could be regarded as "belonging" to a certain person. The privacy-oriented approach in her eyes had the advantage of greater flexibility. In this concept, it is possible to take into account both the autonomy of the individual and the legal interests of third persons. Finally, she exemplified her model by Directive 95/46/EC and the situation under national law in Poland. In the subsequent discussion, many contributions spoke in favor of the property-oriented model, or at least a combination of both models. A definite answer, however, was not found.

The last two contributions had their focus on administrative law. The first one by Margrit Seckelmann (Speyer) had to do with "governance" through ethics commissions in the field of medicinal product law. Seckelmann concentrated on ethics commissions for the implementation (in contrast to the preparation) of laws in this field. It was asked whether decisions of those commissions could be regarded as "acts of the administration" (Verwaltungsakte). Seckelmann argued that this was so, due to the changes effected by the twelfth amendment of the German Law on Medicinal Products (Arzneimittelgesetz). She then dealt with different concepts of legitimacy of ethics commissions. Democratic legitimacy was found to be not the only possible solution. Other concepts could also be to safeguard fundamental rights by procedural means or to create acceptance within the community. Another aspect was the question of who should have locus standi before the courts against decisions of ethics commissions. Here, Seckelmann suggested the introduction of group actions known from German environmental law.

The presentation by Süleyman Kolcu (Bielefeld) finally dealt with "Pharmaceutical Residues in Drinking Water". He demonstrated that pharmaceutical residues could get into drinking water in different ways, e.g. through human excrements, sewage sludge or waste dumps. The long-term effect of these residues, even of negligible quantities, is still uncertain. This problem could be solved either by prevention or by elimination. As for prevention, he discussed biodegradable packaging, packages containing smaller numbers of drugs (in order to avoid remaining drugs that were no longer needed) and prohibiting the use of sewage sludge by farmers. With regard to elimination, he held the view that under Directive 2004/27/EC, pharmacists should be obliged to take back remaining drugs. Currently, pharmacists in Germany do so only on a voluntary basis.

In summary, it might be said that once again, the meeting of German-speaking Public Law assistants was a forum for innovative ideas and fruitful discussions. Vienna was, of course, a highly attractive and most impressive venue. Thanks to the perfect organization by our Viennese colleagues, the days in Vienna will remain unforgettable for all participants. As usual, the results of the meeting will be 
published in book form ${ }^{15}$. The next meeting will take place in Berlin from 6 to 10 March 2007, the topic of discussion then being "Networks".

${ }^{15}$ ELISABETH DUjmovirs et Al. (ED.), RECHT UND MEDIZIN, ISBN 3-8329-1810-8, to be published. 